\title{
Aboriginal Students and the Delivery of Citizenship Education
}

\author{
Frank Deer (University of Manitoba)
}

\begin{abstract}
Aboriginal people, one of Canada's most significant ethnic groups in regard to population and growth, are in crisis. This crisis can be characterized as one of social positioning where conditions of poverty, lack of opportunity, and other elements of marginalization are symptoms. Aboriginals and non-Aboriginal scholars have engaged in numerous discussions regarding what can be described as a struggle for a state of dignity in Canada. Citizenship education, an aspect of contemporary schooling that embraces such notions as equality, tolerance, and social justice, is reputed to provide some direction in regard to how all Canadians can develop and prosper regardless of ethnic or cultural background. This article will explore citizenship education and its possible implications for Aboriginal students in Canada.
\end{abstract}

\begin{abstract}
Résumé
La population aborigène canadienne est en crise bien qu'elle représente le groupe ethnique le plus important du pays quant au nombre d'habitants et à la croissance démographique. Cette crise peut être caractérisée comme étant une crise de position sociale dont les principaux symptômes sont la pauvreté, le manque d'opportunités et bien d'autres éléments représentatifs de la marginalisation. Les intellectuels aborigènes et non aborigènes mènent de nombreuses discussions sur ce qui pourrait être décrit comme une lutte pour un état de dignité au Canada. L’enseignement de la citoyenneté, un aspect contemporain de l'éducation canadienne fait référence à des notions comme l'égalité, la tolérance ou encore la justice sociale. Elle est reconnue pour offrir des solutions éducatives qui mènent les canadiens à se développer et à prospérer sans tenir compte des origines ethniques et culturelles. Cet article va explorer cet enseignement de la citoyenneté et les implications qui pourraient en découler pour les étudiants aborigènes au Canada.
\end{abstract}

\section{INTRODUCTION}

Aboriginal people in Canada occupy a position of marginal social standing, and have for some time (Alfred, 1999; Daes, 2000; Deer, 2006a). Although Aboriginal and non-Aboriginal people in Canada and throughout the world are making efforts toward rectifying such inequalities (Moeke-Pickering et al., 2006), the marginalization of Aboriginal people in Canada is still a reality (Battiste \& Henderson, 2000; Reimer, 2006). With Canada's Aboriginal population having experienced significant growth in recent years, especially in urban areas (Statistics Canada, 2001), it may be important to note that this growth is occurring in environments where unemployment, lack of education and opportunity, criminal activity, and racism are creating barriers for social development (Deer, 2006b, Bear-Nicholas, 1996, Friesen \& Friesen, 2002). Traditionally, the task of correcting such social ills has been, in large part, placed upon Canada's education system (Emberley \& Newell, 1994). Although schools are accessible in virtually all urban areas and to children in many First Nations 
communities (Barman, Hebert, \& McCaskill, 1986), serious social problems remain prevalent for Aboriginal peoples in Canada (Statistics Canada, 2001). Education can serve an essential role in addressing such problems, but how that process is enacted may be subject to further thought and discussion (Castellano, Davis, \& Lahache, 2000; Urion, 1993).

Does the social displacement of Canada's Aboriginal peoples constitute a crisis? Writers such as Bear-Nicholas (1996), Battiste (2000), and Abele, Dittburner \& Graham (2000) have characterized the effects of colonization, loss of identity, estrangement from other Canadians, and lack of trust in government as resulting in a position where Aboriginals find themselves at a critical juncture. This critical position is one where, if not addressed adequately, may result in the loss of elements of Aboriginal identity, heritage, language, and a continued occupation as a marginalized people in the lower echelons of Canadian society. In recent years, numerous volumes developed by respected scholars from Canada and around the world have explored situations of marginalization and disenfranchisement related to Aboriginal people. As Schissel \& Wotherspoon (2003) wrote:

Aboriginal people's expectations are high that education carries with it the means to improve their life prospects, and they are clearly aware that schooling as they know it must be retooled to enhance the chances that their aspirations can be achieved. (p. vii)

The improvement of life prospects, reaffirmation of identity and heritage, and the transcendence from a state of marginalization are a few stated goals in the literature of Aboriginal education: the general implication is that there is a gap between such goals and the current state of affairs. This gap may be overcome through the acquisition of education, but such an assertion should be made with one important caveat: education is, and should be, a means to prepare children to be effective contributors to society ( $\mathrm{Li}, 2002)$. One may posit that the goals related to Aboriginal social betterment requires some measure of participation in the society in question (Magsino, 2002; Sears, 1996), participation that involves civic responsibilities such as voting and national service (Heater, 1999). This may be particularly true for Aboriginal people living in Canada's urban areas (Friesen \& Friesen, 2002). However, developments in the area of Aboriginal self-government and cultural revitalization may make Aboriginal identity in Canada, to a certain degree, incompatible with widely-held conceptions of Canadian citizenship (Battiste \& Semaganis, 2002).

This article will explore citizenship education and its possible implications for Aboriginal students in Canada. In discussing issues related to citizenship education, the author recognizes and affirms the cultural 
distinctiveness that is an essential element of Aboriginal heritage and consciences. Additionally, the author recognizes and affirms the importance of Canada's multicultural context and its relevance to national social betterment. Essential to this discussion on citizenship are the relationships between Aboriginals and non-Aboriginals in all forms. For the purposes of this article, citizenship education refers to the process of education that is designed to help develop citizens who are capable of contributing to the social and economic betterment of their local society and of Canada as a whole.

\section{ABORIGINALS AND THE MANDATE OF CITIZENSHIP EDUCATION}

Aboriginal people are a significant and legitimate part of Canadian society (Barsh, 2005). Aboriginal people's status as citizens is codified in Canada's constitution (Ignatieff, 2000), although their relationship with other nonAboriginals and with government can be regarded as unique (Cassidy, 2005). These facts readily legitimate Aboriginal participation in social and political activities in an effort to advance their interests (Battiste \& Semaganis, 2002); such activities can represent an essential element of Canadian citizenship (Hebert \& Wilkinson, 2002). The Assembly of First Nations (AFN) and the First Peoples National Party of Canada (FPNPC) are examples of institutions where Aboriginal people in Canada are organizing themselves in an effort to solidify and improve their relationships with other Canadians. The last few decades may be regarded as a renaissance when Canada's Aboriginal people have progressively asserted their interests and acquired the respect and recognition they desire.

The assertion and recognition of Aboriginal rights and interests may merit consideration when considering Aboriginal participation in Canadian society. The interests that are advanced by organizations such as the AFN and FPNPC are closely related to inherent and constitutional rights, some of which are intended for Aboriginal people (Otis, 2006), while others are enjoyed by all Canadians (Orend, 2002). Although the enjoyment and exercise of rights are important aspects of citizenship, rights are only one element of citizenship. The term citizenship, which can be defined as "membership in a community...the quality of an individual's adjustment, responsibility, or contribution to his community” (Marshall, 1973 p. 84), has existed since ancient times (Heater, 1990). In spite of the rich historic pedigree of the term, developed and agreedupon notions of citizenship are still debated, especially in Canada (Birch, 1999). These debates are prevalent in the area of education (Hebert \& Wilkinson, 2002). Citizenship Education

Educating children for citizenship is a school objective that has been the subject of discussion and development in the Canada since the mid 1990s (Young 
\& Graham, 2000). This development was part of a school improvement initiative introduced in many educational jurisdictions in the 1990s when identified citizenship education was identified as a principal goal (Sears, Clarke, \& Hughes, 1998). For example, in the provinces of Manitoba, Saskatchewan, Alberta, and British Columbia, as well as the Yukon, Northwest Territories, and Nunavut, these efforts were, in part, a collaborative effort through the Western Canadian Protocol for Collaboration in Education. WNCPCE was a collaboration intended to identify shared educational goals and to develop quality educational standards (WNCPCE, n.d.). Western Canadian Protocol for Collaboration in Basic Education's (2002) guidelines document for Social Studies education, The Common Curriculum Framework for Social Studies, was intended to address the needs of modern students as well as the issues of citizenship and Canadian identity:

It is reflective of the diverse cultural perspectives, including Aboriginal and Francophone, that contribute to Canada's evolving realities. The Framework will ultimately contribute to a Canadian spirit - a spirit that will be fundamental in creating a sense of belonging for each one of our students as he or she engages in active and responsible citizenship locally, nationally, and globally. (p. 3)

In addition to the new developments for citizenship education, many educational jurisdictions in Canada enacted developments in the area of Aboriginal education (Young \& Graham, 2000).

WNCPE, as well as other government agencies responsible for education, developed policy and curriculum documents related to Aboriginal schooling. In recent years, education authorities across Canada have continued to take steps toward education reform and improvement in this area (Hebert \& Wilkinson, 2002). For example, in Manitoba, the agenda for school success (Manitoba Education, Training and Youth, 2002) outlined priorities and strategies for numerous aspects of schooling in Manitoba, including Aboriginal Education: "Information on successful strategies to increase success for Aboriginal learners is being shared...the department works with many partners creating opportunities to share appropriate practice related to the education of Aboriginal Children” (p. 12). In this document, Manitoba's commitment to the success of Aboriginal students is put forth as a response to broader social issues: "In the absence of academic success, students lack the skills needed to secure relevant training and employment, and to participate fully as citizens. As a consequence, the costs to the individual and society as a whole are significant" (p. 11). The Province of Ontario has developed similar goals related to Aboriginal student development, which identified graduation, access to and 
completion of post-secondary education, career preparation, and relevant research as its principal objectives (Ontario Ministry of Education, 2007).

Little has been written regarding the relationship between Aboriginal students and citizenship education. Aboriginal Canadians' status as Canadian citizens with distinct rights and histories, have a problematic relationship with Canadian citizenship and identity (Varadharajan, 2000). Canada's current ethnic landscape, the result of decades of immigration, social evolution, and political progress, is so diverse that it is difficult to conceptualize what being Canadian is all about (Hebert \& Wilkinson, 2002). In exploring this issue and its impact on Canada's First Peoples, Cardinal (1977) suggested that Canadian identity is a concept that should be developed by an individual's subjectivities:

In Canada there is no such universally accepted definition of the concept of Canadianism. There is no easy, sure national identity for Canada or for Canadians....Unless we reach a common agreement on the meaning of that term, we must always define the concept as we understand it, so that others will know what we mean when we discuss Canadianism. For too long, both the white and the Indian political leaders have been involved in a Quixotic battle. Our imaginary windmills have been our varying concepts and definitions of what being Canadian is all about. (p. 9)

Cardinal's insights are shared by Battiste and Semaganis (2002), who asserted that an individual's identity is developed by "reciprocal relationships among individuals...because no individual knows what that path is for another, each has the independence and security to discover that path without interference” (p. 97). These sentiments illuminate an important issue for citizenship education in Canada: how are the values, histories, and beliefs of Canada's First Peoples addressed in citizenship education? As Strong-Boag (2002) stated, "Aboriginal and working class activists...point to the hegemonic state's persistent misrecognition of or total blindness to their interests...recognition of the full humanity, or, more narrowly, the full citizen of different groups of Canadians is at issue” (p. 37). Arguably, any policy or social reform developed by government authorities, that will be relevant to Canadian citizenship education, requires awareness of, and sensitivity to, the interests of minority groups. Furthermore, any education program that enacts such policies in an effort to educate for Canadian citizenship must also exercise such awareness and sensitivity.

\section{VALUES: THE TENETS OF CANADIAN CITIZENSHIP}

In the diverse cultural and ethnic landscape that typifies Canada, the issue of what it is to be Canadian has become very prevalent (Sears, Clarke, \& Hughes, 1998). Beyond the basic principle of bearing allegiance to a national identity, 
citizenship in Canada is personified by the values of equality, tolerance, social justice, and social responsibility (Citizenship and Immigration Canada, 2004). All citizens of a democratic state such as Canada have a responsibility to not only strive to embody such values of citizenship, but to exercise those values through active citizenship (Cogan, 2000). These values of active citizenship can be exercised by making a positive contribution to community and society, and that the acceptance of these values and responsibilities are crucial elements for individual wholeness (Karsten, Kubow, Matrai, \& Pitiyanuwat, 2000). Aboriginal Canadians, those who are of a culture and lineage that predates European colonization and is indigenous to pre-colonial Canada (Barman, Hebert, \& McCaskill, 1986), have been identified as distinct in regard to their ethnic and cultural background (Longboat, 1987; Medicine, 1987, Citizenship and Immigration Canada, 2004). When one compares commonly held conceptions of Canadian citizenship against the state-of-affairs in which most Aboriginal Canadians currently exist, discrepancies abound and the notion of citizenship and national identity can be attenuated (Battiste \& Semangis, 2002; White, 2003). This problem becomes further palpable when one considers that Aboriginal Canadians are a significant and growing portion of Canada's population (Statistics Canada, 2001; Citizenship and Immigration Canada, 2004). Canada's education system has been called upon to deal with this problem through the development of curricular mandates that emphasize the skills of active citizenship.

The term citizenship has yielded a number of divergent definitions about what being a citizen entails (Hebert \& Sears, 2001; Giroux, 1997). Among the various conceptions of citizenship that are applicable to the Canadian context lie a number of basic notions that relate to the country in which one inhabits and what rights are applicable to a citizen (Government of Canada, 1985a). A sufficient definition of citizenship in the Canadian context requires more expansion beyond related legislation and necessitates a focus on the values that can be associated with being a Canadian citizen (Magsino, 2002). The values of Canadian citizenship can only be suitably explained by presenting it against the backdrop of Canada's multicultural society (Citizenship and Immigration Canada, 2004). Contemporary Canadian society can be characterized as a plethora of different cultures that are represented by people from numerous countries (Stewin \& McCann, 1993). This diverse cultural mosaic necessitates a call for a framework of values that will not only pay courtesy to disparate ethnic and cultural backgrounds, but also encourage the harmonious existence of these backgrounds in one country (Ignatieff, 2000; Emberley and Newell, 1994). 
The framework of values that define citizenship in Canada are illustrated by Citizenship and Immigration Canada's (2004) conception of what Canadian citizenship means. Canada's framework of values (Deer, 2008) that constitute citizenship, which are sometimes referred to as democratic values, include:

- Equality: The respect for everyone's rights, and the mandate for government to treat everyone with equal respect and dignity.

- Respect for Cultural Differences: The attempt to understand and appreciate the customs, cultures, and traditions of all Canadians.

- Freedom: The right to basic freedoms such as freedom of thought, speech, religion, and peaceful assembly.

- Peace: The sustenance of a non-violent society and the aim to help others around the world realize peace.

- Law and Order: Democratic decision making has developed laws that ensure peace and justice. Government is expected to remain accountable to Canada's citizenry.

- Environmental Stewardship: The value for establishing and maintaining a suitable, ecologically sound environment for present and future generations.

This framework of values for Canadian citizenship offers a guideline for what can be termed active citizenship. Active citizenship, the act of being a responsible citizen who contributes to his/her society, involves a number of responsibilities that are closely associated with not only the values listed above, but of others that are less often discussed in academic discourse but are essential to the maintenance of a democratic state. Cogan (2000) describes active citizenship as one of five dimensions of citizenship that addresses the responsibilities, obligations, and duties that all people have by virtue of being a citizen. In a discourse that recognizes that modern Western Society has come to neglect such responsibilities, obligations, and duties while putting more emphasis on individual rights and freedoms, Cogan (2000) asserted that:

Citizenship carries with it the obligation to perform certain duties, including the responsibility to obey the law, to pay one's taxes, to respect the rights of other people, to fight for one's country and generally to fulfill one's social obligation. (p. 4)

Although duties and obligations represent an important element of citizenship, Cogan suggested that citizenship consists of five essential attributes:

- A sense of identity

- The enjoyment of certain rights

- The fulfillment of corresponding obligations

- A degree of interest and involvement in public affairs, and 
- An acceptance of basic societal values.

These attributes, coupled with the values outlined earlier, constitute a conception of Canadian citizenship that emphasizes appropriate civic participation and the acceptance of social ideals intended to foster a harmonious climate amongst all Canadians.

There are a small number of items within these frameworks that may provide tension for Canada's Aboriginal peoples, perhaps none as contentious as the concept of identity. In the midst of a national multicultural mosaic where they occupy an arguably problematic social position (Alfred, 1999; Battiste, 2000), affiliating one's self with Canadians of non-Aboriginal descent as a means of establishing a shared identity may be one of the more difficult challenges for Aboriginal youth in Canada. With such problems in mind, the establishment of identity as a concept may be essential to the solidification of Canadian citizenship. Establishing Canadian identity may only be accomplished by solidifying the definition of identity itself; a definition that celebrates race, language, heritage, and other facets of diversity prevalent to Canada.

\section{DISCUSSION}

Citizenship education, as it applies to Aboriginal people in Canada, is still an emergent field in Canada. As opposed to having a focus on national loyalty and civic responsibilities, citizenship education for Aboriginal students in Canada may be best addressed by focusing on the basic skills that can be associated with citizenship education in a way that gives appropriate privilege to Aboriginal identity. In their most basic form, these skills represent social imperatives that are beneficial to the development of social harmony in Canada. As many have noted in the contemporary writing on the subject, citizenship education can be encouraged in multiple facets of student experiences that go beyond the limitations of academic programming in a classroom. In other words, educating for citizenship can best occur through practical experience and effective modeling: a process in which values can be applied to behaviour and their meaning and consequences can be better appreciated. This insight may be an essential consideration when working with Aboriginal students, a group whose proclivity for experiential learning has been emphasized (Friesen \& Friesen, 2002).

In his seminal work The Rebirth of Canada's Indians, Harold Cardinal made note of two important problems in regard to Canadian citizenship and Aboriginal people. Firstly, he emphasized the vagaries of Canadian identity as a concept. Written in 1977, Cardinal asserted that there is no widely agreed-upon definition of what could be termed Canadianism, or what can be otherwise 
referred to as the constituent elements of Canadian identity. Arguably, this problem of definition is still the case today. Being Canadian means different things to different Canadians, and historical injustices may be prevalent for Aboriginal people such that acceptance of a national identity may be problematic.

Secondly, in venturing opinions regarding the struggle for opportunity and empowerment for Aboriginal youth, Cardinal asserted the importance of mentoring on the part of parents and teachers in youth development. In quoting the infamous paper Indian Control of Indian Education (1977, p. 59) Cardinal wrote:

We want education to give our children a strong sense of identity, with confidence in their personal worth and ability. We believe in education: ....as a preparation for total living,

... as a means of free choice of where to live and work,

... as a means of enabling us to participate fully in our own social, economic, political and educational advancement.

Cardinal, an Aboriginal of Cree descent, recognized the importance of unity amongst all Canadians as a foundation for a good future for all Canadians. With that imperative in mind, what is the Canadian identity that would be appropriate for Canada's Aboriginal people? Identity can be thought of as an important component of citizenship, but for clues to what Canadian identity consists of, an argument can be made to abandon the stereotypes that one may associate with commonly held conceptions of identity, particularly those that are associated with those ethnicities and nationalities that are homogenous.

Citizenship is an awkward subject in Canada due, in part, to its discomfited association with identity. Most school curricula in Canada address skills and outcomes that may be associated with specific citizenship values. Such curricula in Canada deals with citizenship as a scholarly topic; a process that can and should be employed throughout all aspects of school operations, not just in the social studies class (Levin, 1998). A concern regarding these processes of citizenship education may be that they leave students and teachers with a denotative understanding of citizenship as a concept; one that is substantiated by example only and does not offer insight into the rational or philosophical underpinnings of the concept. The problem for those involved in education, when faced with the issue of discussing Canadian citizenship, is the issue of addressing its implementation with the citation of vague principles, standards, and behavioural imperatives. Identity is inextricably connected to citizenship, and to omit the significance of Aboriginal identities from the Canadian conception of citizenship is to maintain an undue status quo. 
In education, Aboriginal students are often exposed to subject matter that does little to facilitate the development of an identity that is informed by their traditional cultures (Saunders \& Hill, 2007). Mainstream educational programming that is provided to many Aboriginal students may provide skills necessary for developing good citizens, but such programming is carried out with an omission of Aboriginal content that is culturally congruent with the students in question and provides opportunities to challenge Canada's cultural status-quo (Critchly et al., 2007). Language recovery, development of community relationships, and acquisition of traditional knowledge are activities that can provide Aboriginal students with opportunities for citizenship education that are congruent with traditional concepts of Aboriginal identity (Neganegijig \& Breunig, 2007). 


\section{References}

Abele, F., Dittburner, C., \& Graham, K.A. (2000). Towards a shared understanding in the policy discussion about Aboriginal education. In M.B. Castellano, L. Davis, \& L. Lahache (Eds.), Aboriginal education: fulfilling the promise. Vancouver, BC: UBC Press, pp. 3-24.

Alfred, T. (1999). Peace, power, righteousness: An indigenous manifesto. Don Mills, ON: Oxford University Press.

Barman, J., Hebert, Y., \& McCaskill, D. (1986). The legacy of the past: An overview. In J. Barman, Y. Hebert, \& D. McCaskill (Eds.), Indian Education in Canada: Volume 1 The Legacy. Vancouver, BC: University of British Columbia Press. pp. 1-22.

Barsh, R.L. (2005). Aboriginal peoples and Canada's conscience. In D.R. Newhouse, C.J. Voyageur, \& D. Beavon (Eds.), Hidden in plain sight: Contributions of Aboriginal peoples to Canadian identity and culture. Toronto, ON: University of Toronto Press. pp. 270-291.

Battiste, M. (2000). Maintaining Aboriginal identity, language, and culture in modern society. In M. Battiste (Ed.), Reclaiming Indigenous voice and vision. Vancouver, BC: UBC Press. pp. 192-208.

Battiste, M., \& Henderson, J.Y. (2000). Protecting Indigenous knowledge and heritage: A global challenge. Saskatoon, SK: Purich Publishing.

Battiste, M., \& Semaganis, H. (2002). First thoughts on First Nations citizenship: Issues in education. In Y.M. Hebert (Ed.), Citizenship in transformation in Canada. Toronto, ON: University of Toronto Press. pp. 93-111.

Bear-Nicholas, A. (1996). Citizenship education and Aboriginal people: The humanitarian art of cultural genocide. Canadian and international education, 25(2), 59-107.

Birch, A.H. (1999). Reflections on ethnic politics. In A.C. Cairns, J.C. Courtney, P. MacKinnon, H.J. Michelmann, \& D.E. Smith (Eds.), Citizenship, diversity, and pluralism: Canadian and comparative perspectives. Montreal, QC: McGill-Queen’s University Press. pp. 58-71.

Cardinal, H. (1977). The rebirth of Canada's Indians. Edmonton, AB: Hurtig.

Cassidy, M. (2005). Treaties and Aboriginal-government relations, 1945-2000. In D.R. Newhouse, C.J. Voyageur, \& D. Beavon (Eds.), Hidden in plain sight: Contributions of Aboriginal peoples to Canadian identity and culture. Toronto, ON: University of Toronto Press. pp. 38-60.

Castellano, M.B., Davis, L., \& Lahache, L. (2000). Introduction. In M.B. Castellano, L. Davis, \& L. Lahache (Eds.), Aboriginal education: Fulfilling the promise. Vancouver, BC: UBC Press. pp. xi-xviii.

Citizenship and Immigration Canada. (2004). A look a Canada. Ottawa, ON: Author

Cogan, J.J. (2000). Citizenship education for the $21^{\text {st }}$ century: Setting the context. In J.J. Cogan \& R. Derricott (Eds.), Citizenship for the $21^{\text {st }}$ century: An international perspective on education. London: Kogan Page Limited. pp. 1-21.

Critchly, K.A., Timmons, V., Walton, F., Bryanton, J., McCarthy, M.J., \& Taylor, J. (2007). Mi’kmaq children's perceptions of education. Canadian Journal of Native Education, 30(2), 217-230.

Daes, E. (2000). Prologue: The experience of colonization around the world. In M. Battiste (Ed.), Reclaiming Indigenous Voice and Vision. Vancouver, BC: UBC Press. pp. 3-8.

Deer, F. (2006a). Research perspectives in Indigenous education: The legitimacy of Indigenous knowledge. World Indigenous Nations Higher Education Consortium Journal. Retrieved April 20, 2007 from http://www.win-hec.org/docs/pdfs/ FrankDeer.pdf

Deer, F. (2006b). Community-based adult education: Access for Aboriginal residents in the inner-city of Saskatoon. Journal of Aboriginal Economic Development, 5(1), 51-60.

Deer, F. (2008). Citizenship Development for Aboriginal High School Students in the Province of Manitoba: An Exploratory Study. Unpublished doctoral dissertation, University of Saskatchewan.

Emberley, P.C., \& Newell, W.R. (1994). Bankrupt education: The decline of liberal education in Canada. Toronto, ON: University of Toronto Press.

Friesen, F.W., \& Friesen, V.L. (2002). Aboriginal education in Canada: A plea for integration. Calgary, AB: Detselig.

Giroux, H.A. (1997). Pedagogy and the politics of hope: Theory, culture, and schooling. Boulder, CO: Westview Press.

Government of Canada. (1985a). Citizenship act: Chapter C-29 (1974-75-76, c. 108, s. 1). Ottawa, ON: Author. Heater, D. (1990). Citizenship: The civic ideal in world history, politics and education. London: Longman Group. 
Heater, D. (1999). What is citizenship? Cambridge, UK: Polity Press.

Hebert, Y.M. \& Sears, A. (2001). Citizenship education. Canadian Education Association. Retrieved January 25, 2005 from http://www.cae-ace.ca/media/en/Citizenship_Education.pdf

Hebert, Y.M. \& Wilkinson, L. (2002). The citizenship debates: Conceptual, policy, experimental, and educational issues. In Y. M. Hebert (Ed.), Citizenship in transformation in Canada. Toronto, ON: University of Toronto Press. pp. 3-36.

Ignatieff, M. (2000). The rights revolution. Toronto, Canada: House of Anansi Press.

Karsten, S., Kubow, P., Matrai, Z., \& Pitiyanuwat, S. (2000). Challenges facing the $21^{\text {st }}$ century citizen: Views of policy makers. In J.J. Cogan \& R. Derricott (Eds.), Citizenship for the $21^{\text {st }}$ century: An international perspective on education. London: Kogan Page Limited. pp. 109-130.

Levin, B. (1998). The educational requirement of democracy. Curriculum Inquiry, 28(1), 57-79.

$\mathrm{Li}, \mathrm{Z}$. (2002). The administrative practices of principals toward the goal of preparing students for citizenship in Manitoba's high schools. Unpublished doctoral dissertation, University of Manitoba, Winnipeg.

Longboat, D. (1987). First nations control of education: The path to our survival as nations. In J. Barman, Y. Hebert, \& D. McCaskill (Eds.), Indian Education in Canada: Volume 2 The Challenge. Vancouver, BC: University of British Columbia Press. pp. 22-42.

Magsino, R. F. (2002). From eclectic theory to coherence: Citizenship virtues for our time. In Y. M. Hebert (Ed.), Citizenship in transformation in Canada. University of Toronto Press. pp. 57-80.

Manitoba Education, Training and Youth. (2002). Manitoba K-S4 education agenda for student success, 20022006. Winnipeg, MB: author.

Marshall, T.H. (1973). Class, citizenship, and social development. Westport, CT: Greenwood Press.

Medicine, B. (1987). My elders tell me. In J. Barman, Y. Hebert, \& D. McCaskill (Eds.), Indian Education in Canada: Volume 2 The Challenge. Vancouver, BC: University of British Columbia Press. pp. 142152.

Moeke-Pickering, T., Hardy, S., Manitowabi, S., Mawhiney, A., Faries, E., van Marrewick, K., Tobias, N., \& Taitoko, M. (2006). Keeping our fire alive: Towards decolonizing research in the academic setting. WINHEC Journal, 2.

Neganegijig, T., \& Breunig, M. (2007). Native language education: An inquiry into what is and what could be. Canadian Journal of Native Education, 30(2), 305-321.

Orend, B. (2002). Human rights: Concept and context. Orchard Park, CA: Broadview Press.

Ontario Ministry of Education. (2007). Ontario First Nation, Métis, and Inuit education policy framework. Toronto, ON: Queen's Printer for Ontario.

Otis, G. (2006). Aboriginal governance with or without the Canadian Charter? In G. Christie (Ed.), Aboriginality and governance: A multidisciplinary perspective. Penticton, BC: Theytus Books. pp. 265-312.

Reimer, B. (2006). Profile of effective practice: Ma Mawi Wi Chi Itata Centre. Journal of Aboriginal Economic Development, 5(1) 14-21.

Saunders, S.R., \& Hill, S. (2007). Native education and in-classroom coalition-building: Factors and models in delivering an equitous authentic education. Canadian Journal of Education, 30(4), 1015-1045.

Schissel, B., \& Wotherspoon, T. (2003). The legacy of school for Aboriginal people: Education, oppression, and emancipation. Don Mills, ON: Oxford University Press.

Sears, A. (1996). "Something different for everyone": Conceptions of citizenship and citizenship education. Canadian and International Education, 25(2), 1-16.

Sears, A.M., Clarke, G.M., \& Hughes, A.S. (1998). Learning democracy in a pluralist society: Building a research base for citizenship education in Canada. Paper prepared for the Council of Ministers of Education, Canada. Toronto, ON.

Statistics Canada. (2001). Aboriginal peoples of Canada: A demographic profile. Retrieved February 1, 2005, from http://www12.statcan.ca/english/census01/ products/analytic/companion/abor/canada.cfm

Stewin, L.L., \& McCann, S.F.H.. (1993). Contemporary educational issues: The Canadian Mosaic ( ${ }^{\text {nd }}$ ed.). Toronto, ON: Copp Clark Pitman.

Strong-Boag, V. (2002). Who counts? Late nineteenth-and early twentieth-century struggles about gender, race, and class in Canada. In Y. M. Hebert (Ed.), Citizenship in transformation in Canada. Toronto, ON: University of Toronto Press. pp. 37-56. 
Urion, C. (1993). First Nations schooling in Canada: A review of changing issues. In L. L. Stewin, \& S. McCann (Eds.), Contemporary education issues: The Canadian mosaic $\left(2^{\text {nd }}\right.$ ed). Toronto, ON: Copp Clark Pitman. pp. 97-107.

Varadharajan, A. (2000). The "repressive tolerance” of cultural peripheries. In M. Battiste (Ed.), Reclaiming Indigenous voice and vision. Vancouver, BC: University of British Columbia Press. pp. 142-149.

Western Canadian Protocol for Collaboration in Basic Education. (2002). The common curriculum framework for Social Studies: Kindergarten to grade 9. Winnipeg, MB: Manitoba Education, Training and Youth.

Western and Northern Canadian Protocol for Collaboration in Education. (n.d.). Western protocol agreement. Retrieved January 9, 2006, from http://www.wncp.ca/ general/wpagreement.html

White, J.P. (2003). Confronting culture with science: Language and public policy. In J.P. White, P.S. Maxim, \& D. Beavon (Eds.), Aboriginal conditions: Research as a foundation for public policy. Vancouver, BC: UBC Press. pp. 131-135.

Young, J., \& Graham, R.J. (2000). School and curriculum reform: Manitoba frameworks \& multicultural teacher education. Canadian Ethnic Studies, 1, 142-155.

Frank Deer is an Assistant Professor in the Department of Curriculum, Teaching, and Learning, Faculty of Education, University of Manitoba and can be reached at deerf@cc.umanitoba.ca 